\title{
A Review of Vittoria Barsotti, Paolo G. Carozza, Marta Cartabia, and Andrea Simoncini (2015): Italian Constitutional Justice in Global Context. Oxford: Oxford University Press
}

\author{
FANNI TANÁCS-MANDÁK*
}

The Italian Constitutional Court is one of the earliest and most successful European example of constitutional judicial review. However there was a significant gap in the relevant English academic literature, as the last thorough analysis on the Italian constitutional justice in English was published in 1971 by Mauro Cappelletti. ${ }^{1}$

The present book aims to fill this significant longstanding void by presenting and explaining the Italian Constitutional Court's structural, procedural and institutional distinctiveness from the other European and American counterparts. Furthermore, the authors' collaboration renders it possible to involve the Court and the distinctive voice of its jurisprudence to the global constitutional dialogue from an academic perspective and also from practical experiences from within the Court, as there are three professors and a constitutional judge among the authors.

The book, divided to two main parts, tends to describe the 'Italian style' constitutional adjudication in a very systematic and detailed manner. To explain the different reasons of its unique evolution, the book illustrates the roots of the pervasive character of the Italian Constitutional Court and its jurisprudence: the ideologically diverse society, the pluralistic Constitution adopted in 1948, the differentiated composition of the Court (including its motives and consequences) and the hybrid model of the judicial review of legislation.

The first part is dedicated to the historical development of the Italian constitutional adjudication (3-39); the institutional set; the jurisdiction and the judicial review system of the Italian Constitutional Court (41-66); the methods applied in its judicial reasoning; its interpretative theories, concepts of reasonableness; its efforts to ensure proportionality and balancing of values $(67-78,82-91)$ and its practice of using transnational law and comparative methods (78-82).

Understanding the peculiar Italian style of constitutional jurisprudence requires starting with the lack of judicial review of legislation in the Liberal era. The first and 'flexible' Italian Constitution of 1848, inspired by the French and Belgian constitutional text, determined the absolute authority of Parliament as a cornerstone of the Italian legal and political thoughts. Using the concept of parliamentary omnipotence in Italy, it was accepted that every law is properly issued as constitutional.

The lack of an independent judiciary also contributed to impossibility of establishing a judicial review system. Ordinary judges were subordinated to the other powers, especially to the executive. Changes in this unfavorable situation only happened with the fall of Fascism in July 1943. After the election of the Constituent Assembly, the Legislative Decree March 16, 1946, n. 9 declared the 'rigidity' of constitutional matters by establishing that

\footnotetext{
* PhD, senior lecturer, National University of Public Service. E-mail: mandak.fanni@uni-nke.hu

1 Cappelletti, Mauro, Judicial Review in the Contemporary World (Bobbs-Merrill 1971).
} 
they could not be modified or derogated by 'ordinary' legislation. This vital change opened the door to a new form of judicial review. The changing trend appeared also in practice as during the Constitutional Assembly ordinary judges were empowered to exercise constitutional control of legislation. This new experiment was also quite significant for the development of the Italian constitutional adjudication because it lasted almost a full decade as the Constitutional Court, introduced by the new Constitution (Arts. 134-137), only started working in 1956. A structural misalignment between the supermajority requirements and the actual composition of the parliament caused a political deadlock which delayed the full composition and activation of the Court.

There was a conflict between the Left and Right parties in the Constitutional Assembly, as the political Left, especially the Communist Party were strongly opposed to the creation of a Constitutional Court, ${ }^{2}$ while the Right parties, leading by Alcide De Gasperi, together with Luigi Einaudi, the first President of the Republic advocated a supreme court that could protect the Constitution and avoid any abuse of political powers. At the end, the Left parties approved the partly parliamentary elected Constitutional Court as they perceived that such an organ would be useful if they lose the elections. Only little time remained to fix the detailed rules on the Court's composition and function as the debates on the necessity of the Constitutional Court lasted a long time. ${ }^{3}$ The Constitution declared only the composition of

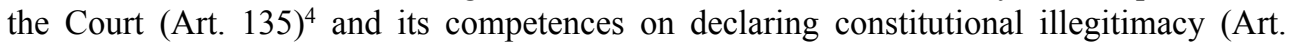
136). ${ }^{5}$ Establishing the Constitutional Court brought a quite new situation and created a significant challenge in the Italian political system, as such an organ was unprecedented in the Italian legal order. With the lack of any reference points, the Italian political leaders took into account foreign examples, such as the Constitutional Courts of the United State and Austria.

The missing regulations were recovered by the Constitutional Law No. 1 of 1948 and further acts, which basically regulated the access to the Court by the incidental and the direct method, given no possibilities to a direct action by an individual citizen. Further peculiarity of the Italian Constitutional Court is that the Justices have no possibilities for writing dissenting opinions. ${ }^{6}$

2 Palmiro Togliatti, the leader of the Communist Party called the idea of the Constitutional Court as 'something bizarre'. (14).

3 One of the most significant constitutionalist, Piero Calamandrei described this situation as a 'paradox', that the future Parliament(s) will have the task to regulate the Constitutional Court by constitutional laws and ordinary statutes because one of the Constitutional Court's powers is to ascertain the constitutional validity of ordinary legislation. p. 41.

${ }^{4}$ The Court shall be composed of fifteen judges, a third nominated by the President of the Republic, a third by the Parliament with qualified majority in joint session and one third by the ordinary and administrative supreme Courts for twelve years. The Justices are all united by a common legal education, but differ completely in their professional trajectories. This kind of pluralism has always been a great asset for the Court as the Justices have been obliged to dialogue with each other. A great added value of the book is the table which presents the Justices' activities before their appointment at the appendix II. (277-85).

5 The Constitution determined that if the Court declares the constitutional illegitimacy of a law or enactment having force of law, the act ceases to have effect on the day following the publication of the Court's decision. The unconstitutional norm decision cannot be used by anyone and the decision of unconstitutionality has a retroactive effect.

${ }^{6}$ This decision was motivated by the intention to avoid any mean to insult the Justices by pressures of politics. 
The birth of the new constitutional adjudication in Italy was framed by different uncertainties which determined its later characters. The first uncertainty was regarding the interpretation of the Constitution, whether to interpret it as a piece of subsequent legislation or a hierarchically supreme norm. The second challenge was that the Constitution contains several 'programmatic' provisions. Ordinary judges, who were empowered to exercise constitutional control of legislation until the Constitutional Court's operation, noted that the Parliament should have approved implementing legislation otherwise these kind of provisions would not be justiciable.

The Court responded to the doubts on the hierarchical legal force of the Constitution by the Judgement $1 / 56 .^{7}$ At this judgement, the Constitutional Court noted its exclusive competence to decide controversies regarding the constitutional legitimacy of laws or other acts having the force of law and declared that for speaking of constitutional legitimacy there is no distinction between laws enacted before or after the Constitution. It established the Constitution as a comprehensive higher law. The Constitutional Court exhibited a new and unprecedented kind of adjudicative style, it engaged in an elaborated, public, reasoned discussion about the normative constitutional order. The Court as asserting its supreme and exclusive authority to judge the constitutionality of laws, interpreted itself as an equal interlocutor among the institutional organs of the constitutional order (30-32). It determined a consequent dialogic relationship with the Parliament. In doing so, the Court broke sharply from the juridical and political characteristics of the Italian legal tradition that would have been hostile to the creation of a true system of constitutional adjudication.

The first Justices of the Court recognized that the success of this organ would depend on its concrete acceptance by the other constitutional actors, especially the Parliament and the Government, and public opinion. For this reason, it insisted from the beginning to give extensive public reasons for its decisions and invented the practice of meeting periodically with journalists. ${ }^{8}$

All the above mentioned tendencies and factors produced the current structure of the Italian system of constitutional adjudication as a result of a complex process of historic layering. The system created in the 1950s was then consolidated in three different paths through the Court's jurisprudential practice; through the improvement of its procedural instruments and through the definition of its relationship with the other political organs (37-38).

In the following parts, the authors present the so-called ambiguous and 'hybrid' Italian system of constitutional justice of which only one part is to ascertain the constitutional validity of legislative acts. It derives primarily from the unresolved question whether the Constitutional Court has a political or a jurisdictional nature. ${ }^{9}$ Its 'hybrid' character comes from it combining different elements of the American (diffuse and concrete) and the Austrian (centralized and abstract) models of judicial review. The Italian model lies between the two mentioned systems as the Constitutional Court exclusively decides a constitutional question but the questions reaches the Court by ordinary judges in specific cases. Thus, the

7 This judgement is often interpreted as the Italian Marburry v. Madison. (30.)

8 It quite differed with this activity from all the other powers.

9 The contradictions are developed by the Justices' election mode in which the political forces can participate actively. The very first example is the election of the first five parliamentary elected Justices. The parliament was able to elect the Justices only after a two year long political conflict when the political parties agreed on the numbers of Justices appointed by the most powerful parties. 
Italian system is centralized (similarly to the Austrian system), but the initiative is diffuse throughout the Judiciary (similarly to the American system) (42-43).

Another element of the Italian Constitutional Court's singularity is the feature of its functioning mode because it adjudicates as a unitary body rather than in panels. The principle of collegiality is a function of the necessity of finding equilibrium between law and politics. The Court applies two methods in its work, the direct method and the incidental method. The direct method has an increasing role in the Court's work especially after the reform on the Title V of the Constitution approved in 2001. The access to the Constitutional Court of Italy is more limited than in other countries as the system does not give the possibility for any person to bring a constitutional complaint before the Court or for parliamentary minority to raise a constitutional question.

A further distinctive mark of the Italian Constitutional Court is that it tends to a 'syncretistic' or 'integrated' reasoning, using a combination of different approaches to constitutional interpretation. Furthermore the Court interprets the Constitution as a whole, avoiding fragmented interpretations detaching from the context of a provision.

One of the most recurring themes in the legal reasoning of the Italian Constitutional Court is the scrutiny based on reasonableness and proportionality. The Italian Constitutional Court uses the word rationality, reasonableness, proportionality, adequacy, coherence and congruity interchangeably (75).

The authors summarize the Italian style of constitutional jurisdiction or the uniqueness of the Italian constitutional adjudication in the term of relationality. Relationality means 'Where in its historical development, its internal working and methods, its institutional relations with other political organs or courts, or its substantive jurisprudence on a number of issues of global concerns, the court at its best operates with a notable attentiveness to the relations between persons, institutions, powers, associations and nations.' (234)

This relational approach to constitutional adjudication can be found in several aspects of the Court's work. Institutional and the interpretative can be distinguished as two types of this relationality. The first one is its relation building capacity. It had to be self-assertive but also cooperative with the parliament. The two organs created an alliance against the fascist legacy. Furthermore, the Court established cooperative relations with other national judicial bodies. Up to the constitutional reform of 2001, the most practiced judicial review method was the incidental method where the ordinary judges played the role of the gatekeepers for the Constitutional Court. On the other side, the Constitutional Court showed a great deal of trust in them. The interpretative relationality appears in the comprehensive methodology which the Court follows in its legal reasoning as it interprets the Constitution as a whole.

The book shows that the Italian Constitutional Court is independent from the branches of powers but it always acts as a member of the 'group', the Constitution assures the final word for the Constitutional Court but it has not been the only actor in constitutional matters.

The second part of the book describes the most important areas of the Italian Constitutional Court's substantive case law in four different areas which presents the peculiarities of the Italian constitutional system: key rights and freedoms (95-154), powers and inter-institutional conflicts (155-82), interrelationship between the central State and the local authorities (183-204), Italy and the European Union (205-30). This part provides an overview of the main challenges with which the Italian Constitutional Court has had to face with since 1955 and also the main developments in its constitutional jurisprudence.

The distinctive voice of the Italian Constitutional Court presented at the case law on fundamental rights has contributed a lot to inter judicial dialogues as it has worked out a consistent jurisprudence which is based on the following two concepts: no individual rights 
is absolute and all rights protected by the Constitution are to be balanced with other rights and relevant public interests. On the basis of the Court's above described relational interpretation of the Constitution, it follows the concept of l'homme situé, so it handles the person in context and divides fundamental rights capturing the diverse relations of the human and social experience (civil, ethical, social, economic and political) (95-154).

One of the basic concept of the Italian Constitution is a strong institutional pluralism which created complex relationships among the branches of powers. Due to this complexity, there are continuous 'conflicts of attributions' among the powers which have to be settled by the Constitutional Court. These conflicts can be appeared among the constitutional organs (horizontal allocation of powers), between the State and the Regions or among the Regions (vertical allocation of powers). The Court is the ultimate supervisor and the guarantor of the institutional framework as it ensures that all the procedures and limits are respected. In doing so, the Court is not only the judge of the law but also the judge of the powers.

The case law on powers is one of the most interesting part of the book as the Constitutional Court is usually heavily criticed because of the frequency of its in-politics activities. This part presents famous and meaningful case laws of conflicts of attribution between the Government and the President of the Republic, Government and Parliament, Judiciary and Parliament, Judiciary and President of the Republic.

The third important topic discussed among the selected case laws is the relation between the central Government and the lower levels of public administration. Italy is a regional State determined by the Constitution which means a very peculiar balance of power between central State, Regions and local autonomies. Since the constitutional reform of 2001 which strengthened the role of local authorities vis-á-vis the central State, the Court has continuously growing number of cases on the local authorities' legislative, administrative and financial autonomies.

The fourth case law section is dedicated to the relations between the Italian Constitutional Court, the European Courts and foreign Courts. The Italian Court maintains an implicit, silent, though influential attention to their decisions and entered into an active relationship with these courts especially in human rights cases. Preceding this actual positive relation, the Italian Constitutional Court had to take a so called 'European journey' starting from its resistance to the supremacy of European legislation, through the phase of the limitations of sovereignty and the constitutional surrender to the supremacy of EU legislation (207-22).

This book fills a large gap as it presents not only a systematic description of the Italian Constitutional Court and its singularity but it also explains what kind of elements and factors caused and evaluated the peculiar characters of the constitutional Court. This background information is essential and indispensable to understand correctly the jurisdiction of the Court. The book's further added value is the applied case law method which ensures to verify the theories of the Court's judicial review in practice.

However, a strong critic of this book is that the authors present only the positive aspects of the Constitutional Court selecting certain cases - while they do not explain the negative aspects of the 60 year history of the Italian Constitutional Court The analysis of these negative aspects would render more complete picture of the Court although the authors declare that the aim of the book is not a critical evaluation of Italian constitutional law. 